\title{
Brand Association of Ciletuh - Palabuhanratu Geopark Towards COVID-19 Pandemic and Sustainable Tourism
}

\author{
Kasno Pamungkas ${ }^{1}$, Eva Tuckyta S. Sujatna ${ }^{1 *}$, Heriyanto ${ }^{1}$, Rohaidah Haron ${ }^{2}$, Mega F. Rosana ${ }^{3}$ \\ ${ }^{1}$ Linguistics Department, Universitas Padjadjaran, Bandung 40231, Indonesia \\ ${ }^{2}$ Pusat Pengkajian Melayu, University of Malaya, Kuala Lumpur 50603, Malaysia \\ ${ }^{3}$ Geological Engineering, Universitas Padjadjaran, Bandung 40231, Indonesia
}

Corresponding Author Email: eva.tuckyta@unpad.ac.id

https://doi.org/10.18280/ijsdp.160817

Received: 25 October 2021

Accepted: 17 December 2021

\section{Keywords:}

brand association, sustainable tourism, pandemic, COVID-19, CPUGGp, geopark

\begin{abstract}
The purpose of this research is to investigate brand association of Ciletuh - Palabuhanratu UNESCO Global Geopark towards the COVID-19 pandemic and sustainable tourism. This research employs a qualitative research method with a case study and descriptive statistics model. The data used in this study are primary and secondary ones in which the techniques of data collecting is by observation, purposive random sampling with Likert scale, as well as literature studies. The results of this study show that Ciletuh-Palabuhanratu Geopark is not only a strategic place for tourism activities in the COVID-19 pandemic since it has characteristics to comply health protocols but also able to meet the tourism recovery during the pandemic. The tourism activities provided by Ciletuh-Palabuhanratu Geopark sites meet the concept of quality adventure tourism and in line with sustainable tourism with concerns on balancing the environmental conservation, local economic empowerment, as well as local social and culture preservation. The brand association of Ciletuh-Palabuhanratu Geopark is shown by its tourism product scope and quality which are associated to sustainable tourism, moreover the use occasion is line with the COVID-19 pandemic situation. The attributes of UNESCO Global Geopark also create the values of tourism activities during and after COVID19 pandemic which meet the points of sustainable tourism activities and recoveries.
\end{abstract}

\section{INTRODUCTION}

In the journey of centuries, the outbreaks of disease and pandemics have generated bad effects to many aspects of life such as health, economy, social and the other ones similar to outbreaks of HIV in the end of $20^{\text {th }}$ century, as well as MERS, SARS, and H5N1 in the beginning of $21^{\text {st }}$ century. Nowadays, COVID-19 outbreak has become global pandemic that is considered as the greatest challenge that the people have been fighting against this century since the second World War [1]. Spreading firstly from Wuhan China, then, the virus rapidly spread around the world and categorized as a pandemic by the World Health Organization [2]. In addition, COVID-19 outbreaks also cause a dilemma since many countries either developed or developing ones should prioritize the most effective strategy between anticipating the global threat of COVID-19 or the livelihood and lives of their people [3].

Meanwhile, the COVID-19 pandemic in Indonesia tended to grow in number each month from the outbreak beginning. Indonesia's one-day increases in COVID-19 cases have continued to hit consecutively high in the past few days as the country has constantly recorded more than 4,000 new infections each day [4]. Until now, Indonesia becomes one of the most effected countries in Asia, hence many aspects of life such as health, economy, industry, etc., are badly influenced by the pandemic including tourism sector. Due to COVID-19, many people in the tourism area are unable to carry out their jobs since a lot of tourist attractions and homestays are closed and their visits of local, national even international tourists are limited. For instance, all community-based tourism destinations in West Java Indonesia should apply health protocols and more active in online marketing to start tourism activities in the villages during pandemic [5].

\section{LITERATURE REVIEW}

\subsection{Indonesian tourism before and during COVID-19 pandemic}

Before pandemic, Indonesia is one of the most visited countries for tourism activities in which $65 \%$ tourist visited Indonesia for nature tourism, $30 \%$ for culture one, and the remains $5 \%$ for creativity. These proportions caused the imbalance and impact to the mass tourism in nature destinations. The mass tourism in nature tourism destinations brought bad impact to the environment like what happened in Indonesia, especially in Bali as the most visited destination [6]. It is confirmed with the opinion that COVID-19 crisis presents us with an unexpected opportunity and challenges us to think about the unsustainability of the pre-crisis travel and tourism industry such as oversaturated destinations suffering from 'overtourism' [7]. Some analysts believe that when a crisis has passed, it is returning step by step into a certain level of normal condition or at least to relatively similar situation before the bad situation. Positive statement says that COVID-19 
pandemic would not influence the tourism sector significantly if only the repeated warnings and increasing recurring risks change the climate and become global health emergencies [8]. Looking through from positive perspectives, COVID-19 also has given opportunity to the global tourism industry to reset, particularly the adventure travel for turning its attention away from haphazard development and reconceptualized adventure not just in its classical sense of hard adventure activities but also social and cultural ones, travel that blends natural and cultural experiences as one big adventure [9]. This one also makes a point to micro and small enterprises deeply rooted in the destination and ecotourism products based on the local natural and cultural heritages that do not contribute to overcrowding but offering either high-quality experiences for tourists and high added value to the destination [10]. Health protocols should, covering washing hands, wearing mask, and social distancing, be complied tightly in tourism sites and destinations. The tourism destinations, therefore, should meet the implementation of health protocol. Destination conditions like crowded, overcapacity, closed area are inappropriate and risky for Corona Virus spreading. One of the potential destinations that are enable to meet all conditions mentioned above is Ciletuh-Palabuhanratu UNESCO Global Geopark which is, in this research, abbreviated as CPUGGp.

\subsection{Ciletuh-Palabuhanratu UNESCO Global Geopark (CPUGGp)}

Together with 5 other UNESCO Global Geoparks (UGGp) in Indonesia, namely Batur Geopark, Gunung Sewu Geopark,
Rinjani Geopark, Toba Geopark, and Belitung Geopark, CPUGGp was firstly recognized as a UNESCO Global Geopark (CPUGGp) in 2018 after previously being listed as an Indonesian National Geopark. CPUGGp is surrounded by alluvial expanses with a lot of unique rocks, stones and beautiful landscapes and natural views. In addition to rocky hills, CPUGGp is also rich of beaches with waves liked by some world surfers [11]. CPUGGp has great potential for tourism development including geotourism, cultural tourism, agrotourism, adventure tourism, and marine tourism. Topographically, the geoarea of CPUGGp is shown in Figure 1 which is stretched in 74 villages at 8 districts i.e. Cisolok, Cikakak, Palabuhanratu, Simpenan, Ciemas, Waluran, Surade, and Ciracap, with $126,100 \mathrm{Ha}$ or $1,261 \mathrm{~km}^{2}$ in width, at the southern area of Sukabumi Regency, West Java Province, Republic of Indonesia [12].

\subsection{Sustainable tourism and COVID-19 pandemic}

Sustainable tourism is tourism and associated activities, either now or in the future, deals with regeneration and upcoming productivity of natural resources; contribution of people and communities, customs and lifestyles, and tourism experience as well as equitable share in the economic benefits of local people and communities in the destinations [13].

Specific focus is given to three specific features related to the applicability of sustainable development to tourism, including carrying capacity, control over tourism and mass tourism which represent the challenges to the acceptance and successful application of sustainable development [14].

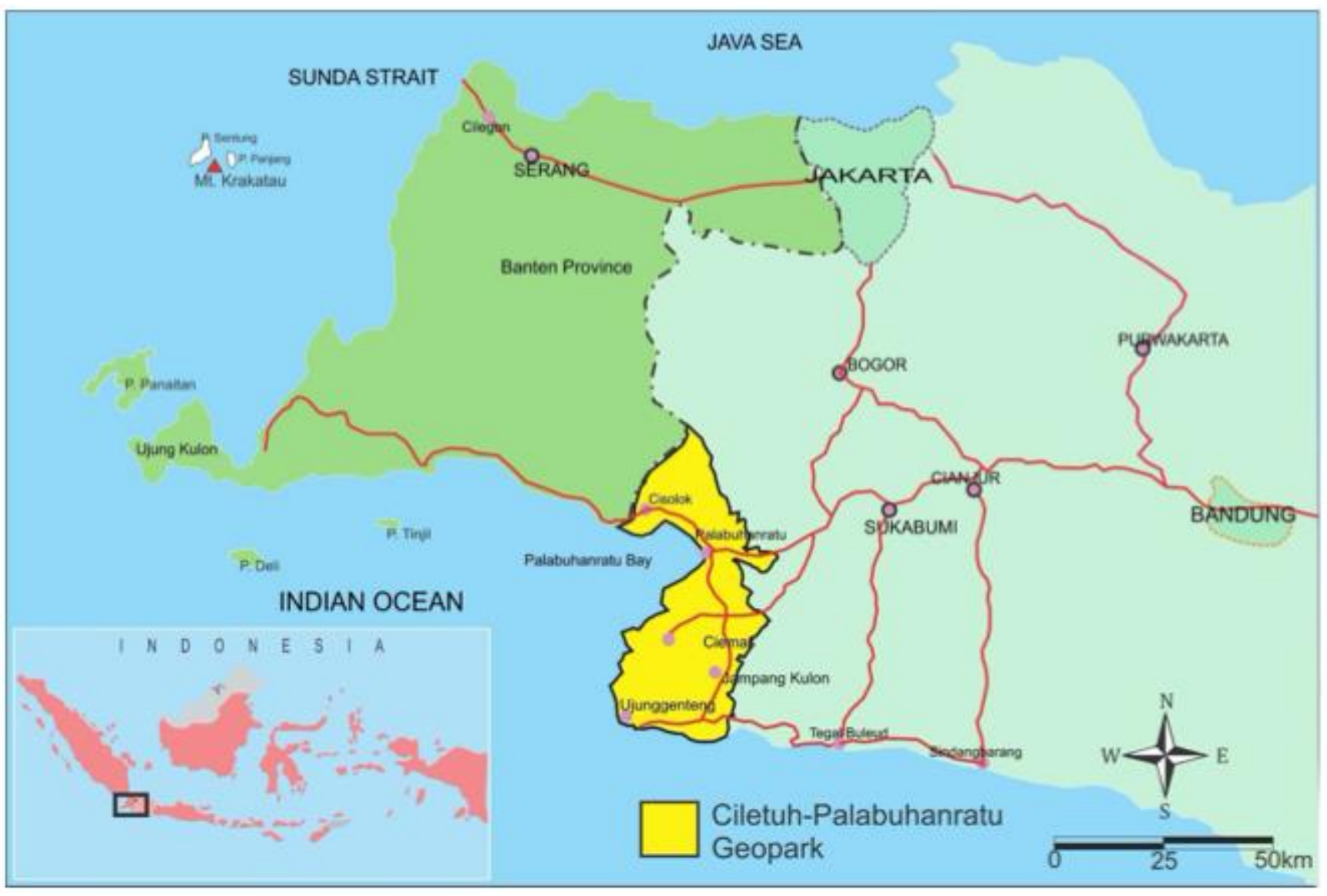

Figure 1. Map of CPUGGp 
The global issue on COVID-19 pandemics become a crucial since it is directly concerned with sustainable tourism principles namely three interconnected aspects: environmental, sociocultural, and economic ones. Some destinations will undoubtedly reconsider the nature of their tourism industry and focus more on local and more sustainable forms of tourism [15]. Sustainability implies permanence and resilience, so that sustainable tourism includes the optimum use of resources, including biological diversity, minimization of ecological, cultural, and social impacts, and maximization of benefits for the conservation of natural and cultural heritages and local communities [16]. Tourism has positive impact on economy, for example the longer the tourists stay, the greater the local income and labor absorption, then the greater the employment, the higher the income of the people in the destination [17]. Regarding to tourism activities in geopark, by emphasizing the general concepts of tourism towards environment, social and culture, as well as economics, geotourism follows the sustainable principles under the sustainable tourism [18]. Geotourism is in line with the geosites located in village and rural areas which are rich of nature and local culture [19].

More optimistic reason states that it is a good moment to take advantage of crisis situation to make far-reaching structural changes to the tourism sector, especially starting with a reflection on its sustainability and resilience [20]. Sustainability drives tourism to get balances on the environment, the social and culture, as well as the economy. Regarding to global sustainable tourism, this opportunity can be optimized for balancing overcrowded tourism in the city of developed countries and bring the crowds to nature in developing countries. Therefore, it is not only to the environment and economy but also to social and culture aspects that the tourism activities will give impacts [10]. Furthermore, the challenge after COVID-19 pandemic is to design for tourism futures by harnessing and channeling environmental hope to heal the natural world [21].

\subsection{Names and brands in CPUGGp}

Place names are, regarding to tourism products and brands, important features of national and territorial identity [22]. In addition, words used as place names play an important role on a regional and national levels in which the names may create strong feelings among large groups of people, especially in multi-ethnic areas towards the place names which have intimate relationship with the places [23]. The product name is not only able to be the identification but also can be a product labelling system, in which in the level of practical information, name has a denotative function which directs consumers to identify what products to buy and product name raises the image going beyond on the connotative level [24].

Branding geopark as (geo)tourism destination is identical to city brands namely the need to clarify their identity and image like the essence and its perception, positive points such as its good quality culture, leisure, and recreation options. The brand is limited differently to the destination and has its own momentum. It should be rooted in reality rather than an imagination and delusion peddled by mendacious advertising. Hence, a destination needs to ensure that they have got the tangible evidences to support its excellences. The names of tourism destinations, with their word formations and toponyms, have brand function since they are informing the area or location of the destination [25]. Furthermore, in geotourism branding, names have important role to communicate the types and characteristics, the facility, and the location of the nature tourism objects and destinations, the nature peculiarities of the destinations, the cultural aspects, and also the religious purposes [6]. It is strengthened with the statement that names of the nature tourism destination play an important role to communicate the types and characteristics, the facility, and the location of the nature tourism objects and destinations to form the nature tourism branding [26].

\subsection{Brand associations}

Research on branding is discussing the markets for consumer and business markets [27]. Hence, it is closely related to human characteristics as consumer, humans' life style and their preferences [28]. Brand associations is helping process of retrieving information, reasoning to buy, creating positive attitude/feelings and extensions. The associations might include product attributes, celebrity spokesperson, or a particular symbol [29]. In the perspective of brand as product, there is product related associations that links to brand choice decisions and the use experience. The followings determine the associations i.e.:

1. The product scope or with what product the brand is associated, such as Visa is for credit cards.

2. The product-related attributes create value proportion by offering something extra such as features or services or by offering something better. In addition, added value and distinctiveness to the brand is provided like McDonald is for unrivalled worldwide products.

3. Quality is an attribute related to product brand which is important to consider separately such as Mercedes Benz, while value is closely related to quality which enriches the concept by adding price dimension.

4. Use occasion in particular situation is important such as Starbucks is for drinking Coffee.

5. Associations with users is to position a brand by a type of user such as Nike is for sport, Johnsons is baby needs.

6. Link to a country or region is placing the brand identical to country or region such as KFC is USA, Spaghetti is Italy, Rendang is Indonesia, etc. [29].

\section{METHOD}

This research is employing qualitative method in which the purpose is to describe condition and phenomenon as well as to emphasize the understanding of the social problem based on the reality [30]. There are two kinds of data used in this research namely primary and secondary data. The primary one is taken from population of the tourist who have visited CPUGGp. Then samples are selected representatively by purposive sampling with some particular and specific criteria [29]. The criteria are the respondents who have ever visited CPUGGp, concern to nature and quality tourism, and understanding condition of COVID-19 pandemic. Purposive sampling is used because not all people have ever visited CPUGGp and in accordance with the criteria. Multivariate analysis is used in this research and the minimum number of sample is $10 \mathrm{x}$ research variables, hence the minimum number of samples is $\mathrm{n}=3 \times 10=30$ [31].

Regarding the instrument validity, Expert Judgement is used in this research. There are 1 dependent and 2 independent variables of research used as the bones of questions. The data collecting is by sharing online questionnaires to the selected 
samples by employing google form which contain some questions based on the 3 variables with Odd 5 point Likert Scale 1-5 of agreement (1: strongly disagree, 2: disagree, 3: neutral, 4: agree, 5: strongly agree). Likert scale is a psychometric scale to collect the opinion and attitudes of respondents, therefore it fits with brand research to identify their views and perspectives of CPUGGp brand associations towards COVID-19 pandemic and sustainable tourism.

Totally, there are 3 variables namely Table 1 (QA1 - QA6) as dependent variable about understanding on CPUGGp's Tourism potencies which consists of 6 statements generated from some sources as research instrument.

As previously mentioned, there are 2 independent variables (QB1 - QB6) about adaptability of CPUGGp towards COVID-19 pandemic in Table 2 consisting of 6 statements adapted from several researchers as instruments.

Another independent variable (QC1 - QC14) is in Table 3 which consists of 14 statements about applicability of sustainable tourism in CPUGGp adapted from many sources as the research instruments of this purposive sampling survey.

The samples are deriving from various elements of society such as academician or researchers, company or industry, government, community, as well as media. Among the qualified samples according to variables of purposive sampling, 60 respondents participated in the survey, then the data of the Likert scale are measured with descriptive statistics. The results of Likert scale are calculated with the following formula:

1. Maximum: $5 / 5 \times 100 \%: 100 \%$

2. Minimum: $1 / 5 \times 100 \%: 20 \%$

Then, the degrees of the respondents' opinion are classified into the following descriptive analysis of percentage that can be seen in Table 4 [32].

The total percentage of the respondent opinion is resulted from the following equation:

$$
P=\frac{\sum X}{n}
$$

note:

P: Percentage

$\sum X:$ total point

n: number of data

Table 1. Dependent variables about CPUGGp's tourism potencies

\begin{tabular}{ccc}
\hline Code & CPUGGp's Tourism Potencies & Sources \\
\hline QA1 & CPUGGp fits for adventure tour & Nepal [9], Adiakurnia [11] \\
QA2 & CPUGGp Blends the nature, social and cultural adventures & Nepal [9], Adiakurnia [11], Hall et al. [15], Zouros\&Martini \\
\hline QA3 & There are micro SMEs in the CPUGGp & Romagosa [10], Adiakurnia [11], Hall et al. [15] \\
\hline QA4 & CPUGGp gives high quality tourism experiences & Romagosa[10], Adiakurnia [11] \\
\hline QA5 & There are Local products and creative economic in CPUGGp & Romagosa [10], Hall et al. [15] \\
\hline QA6 & There are local products based on nature potencies in CPUGGp & Adiakurnia [11], Hall et al. [15], Zouros and Martini [19] \\
\hline
\end{tabular}

Table 2. Independent variables about adaptability of CPUGGp towards COVID-19 pandemic

\begin{tabular}{ccc}
\hline Code & Adaptability of CPUGGp to COVID-19 Pandemic & Sources \\
\hline QB1 & CPUGGp does not contribute to mass tourism & Butler [14], Romagosa [10], Higgins et al. [7] \\
\hline QB2 & $\begin{array}{c}\text { Health protocols for tourist such as wearing mask, hand washing, social } \\
\text { distancing could be complied in CPUGGp }\end{array}$ & Juliana et al. [5], Jamal and Budke [8], Romagosa [10] \\
\hline QB3 & Visitors are able to avoid crowded situation in CPUGGp & Butler [14], Romagosa [10] \\
\hline QB4 & CPUGGp is able to accommodate the visitors and avoid over capacity & Butler [14], Romagosa [10], Adiakurnia [11] \\
\hline QB5 & CPUGGp is an open space tourism with large area & Romagosa [10], Adiakurnia [11], Rosana [12] \\
\hline QB6 & It happens nature conservation during pandemic in CPUGGp & Eber [13], Jamal and Budke [8] \\
\hline
\end{tabular}

Table 3. Independent variables about applicability of sustainable tourism in CPUGGp

\begin{tabular}{ccc}
\hline Code & Applicability of Sustainable Tourism in CPUGGp & Sources \\
\hline QC1 & CPUGGp has nature tourism destinations. & Eber [13], Adiakurnia [11], Hall et al. [15], Farsani et al. [16] \\
\hline QC2 & $\begin{array}{c}\text { There are communities that give contribution to the geopark } \\
\text { and tourism in CPUGGp. }\end{array}$ & Eber [13], Hall et al. [15], Farsani et al. [16] \\
\hline QC3 & CPUGGp has unique and distinctive cultural heritages. & Eber [13], Adiakurnia [11], Rosana [12], Zouros and Martini [19] \\
\hline QC4 & Tourism in CPUGGp supports the economic empowerment. & Eber [13], Romagosa [10], Farsani et al. [16] Yudhoyono [17] \\
\hline QC5 & Tourism activities in CPUGGp gives benefits for local & Eber [13], Adiakurnia [11], Hall et al. [15], Farsani et al. [16] \\
\hline QC6 & Tourism activities in CPUGGp give interesting experience. & Eber [13], Adiakurnia [11], Rosana [12] \\
\hline QC7 & CPUGGp has proper carrying capacity. & Butler [14] \\
\hline QC8 & CPUGGp is able to control over tourism. & Butler [14], Romagosa [10] \\
\hline QC9 & CPUGGp controls mass/conventional tourism. & Butler [14], Higgins et al. [7] \\
\hline QC10 & Tourism in CPUGGp gives positive impact to environment. & Eber [13], Yudhoyono [17], Cottrel et al. [18] \\
\hline QC11 & Tourism in CPUGGp brings positive impact to labor. & Eber [13], Yudhoyono [17], Cottrel et al. [18] \\
\hline QC12 & Tourism in CPUGGp gives positive impact to local income. & [18] \\
\hline QC13 & Tourism in CPUGGp brings positive impact to social & Eber [13], Nepal [9], Adiakurnia [11], Hall et al. [15], Cottrel et al. \\
\hline QC14 & Tourism in CPUGGp gives positive impact to local arts and & Eber [13], Nepal [9], Adiakurnia [11], Hall et al. [15], Cottrel et al. \\
& [18], Zouros and Martini [19]
\end{tabular}


Table 4. Descriptive analysis of percentage

\begin{tabular}{ccc}
\hline No & Percentage & Criteria \\
\hline 1 & $81 \%-100 \%$ & Strongly agree \\
\hline 2 & $61 \%-80 \%$ & Agree \\
\hline 3 & $41 \%-60 \%$ & Netral \\
\hline 4 & $21 \%-40 \%$ & Disagree \\
\hline 5 & $1 \%-20 \%$ & Strongly disagree \\
\hline
\end{tabular}

In order to complete the primary data collection, furthermore, direct observation was conducted in the research location to obtain clear and valid information related to the brand association. It was conducted by visiting some geosites directly in CPUGGp geoarea to see and identify the attractions possessed by the geosites. In addition, a visit to geopark management office is also conducted to get additional information regarding to CPUGGp.

Meanwhile, the secondary data is obtained indirectly from internet, literature study, international journal, book references and other sources related to COVID-19 pandemic, branding theory, toponym theory, geopark and sustainable tourism theories, as well as geotourism. The data obtained during the research are in the form of names of the sites and their meaning description. The data analysis is descriptive one which is firstly begun with classifying them according to their names and characteristics. Then, they are analyzed by using theory of branding association and factual information regarding the condition of COVID-19 pandemic to get the insight of sustainable tourism and tourism in new normal.

\section{RESULTS AND DISCUSSION}

Through site and location visit, observation, and interview with some related informants as well as literature studies, it is confirmed that CPUGGp is covering an area of 126,100 hectares spread across from Cisolok district in the north-west to Ujung Genteng in the southern part of Sukabumi Regency. CPUGGp has several geosites located in all 8 districs which based on their geotourism toponyms or their sites namings, it is identifiable the tourism potencies, description and activities as well as the uniqueness of CPUGGp as the following discussions.

\subsection{Geosites in CPUGGp and their tourism characteristics}

\subsubsection{Geodiversity}

In the tourism sites based on geodiversity of CPUGGp, there are at least 6 types of nature explorations with each unique experiences that the tourists can find. As in Table 5, the visitors are able to enjoy various waterfalls with their views, stories, and interesting spots. According to their names, the waterfalls present their own characteristics such as its geographical location like Curug Cimarinjung and Curug Cidongke, their biodiversity existences around the waterfalls such as Curug Cikanteh, Curug Cigangsa, and Curug Cikaso. Furthermore, the geosite names show their topographic uniqueness and descriptions such as Curug Sodong, Curug Luhur, Curug Tengah, Curug Gentong and their picturesque scene of waterfalls such as Curug Ngelay, Curug Awang, Curug Nyelempet, Curug Puncak Manik, and Curug Mawur.

Having enjoyed the waterfalls, the tourists are suggested to explore the nature by visiting some sightseeing spots from the upper position to enjoy beautiful scenes looks like mega amphitheater of nature as mentioned in Table 6 . Based on their names, employing local language, Panenjoan means a spot in a high or top position from which visitors can look the nature landscape consisting of hill, lower land, cliffs, coastal area, natural garden below. In addition, biodiversity and culture characteristics are also used to name the sightseeing spots such as Puncak Jeungjing and Puncak Darma, while Mega Amphitheater means a vast, wide and big natural amphitheater.

Table 5. Geodiversity: Waterfalls' names and descriptions

\begin{tabular}{|c|c|c|}
\hline No & Names & Meaning \\
\hline 1 & $\begin{array}{c}\text { Curug } \\
\text { Cimarinjung }\end{array}$ & $\begin{array}{c}\text { Waterfall located in Cimarinjung } \\
\text { village }\end{array}$ \\
\hline 2 & Curug Cikanteh & $\begin{array}{l}\text { Waterfall around the area of Tea } \\
\text { plantation }\end{array}$ \\
\hline 3 & $\begin{array}{l}\text { Curug Cikaret / } \\
\text { Ngelay }\end{array}$ & $\begin{array}{l}\text { Waterfall which the flows like } \\
\text { salivating }\end{array}$ \\
\hline 4 & Curug Sodong & $\begin{array}{c}\text { Waterfall with overhanging rock at the } \\
\text { below part }\end{array}$ \\
\hline 5 & Curug Awang & $\begin{array}{l}\text { Waterfall squeezed by a row of red } \\
\text { cliffs combined with brown water and } \\
\text { the blue sky. }\end{array}$ \\
\hline 6 & $\begin{array}{l}\text { Curug Puncak } \\
\text { Jeruk }\end{array}$ & $\begin{array}{l}\text { Waterfall firstly found with lemon tree } \\
\text { at the top area of the geosite }\end{array}$ \\
\hline 7 & Curug Luhur & $\begin{array}{l}\text { The highest waterfall among the other } \\
\text { three ones existing in Cibenda village }\end{array}$ \\
\hline 8 & $\begin{array}{c}\text { Curug } \\
\text { Nyelempet }\end{array}$ & $\begin{array}{l}\text { A slipped waterfall in which the water } \\
\text { is flowing among the rocks }\end{array}$ \\
\hline 9 & Curug Tengah & $\begin{array}{l}\text { The middle waterfall among the other } \\
\text { three ones below the Curug Luhur }\end{array}$ \\
\hline 10 & $\begin{array}{l}\text { Curug puncak } \\
\text { Manik }\end{array}$ & $\begin{array}{l}\text { A sparkling waterfall due to sun rays } \\
\text { meet with water splashes which causes } \\
\text { sparkling sensation }\end{array}$ \\
\hline 11 & Curug Mawur & $\begin{array}{l}\text { Scattering waterfall due to water flows } \\
\text { on the rocks }\end{array}$ \\
\hline 12 & $\begin{array}{c}\text { Curug } \\
\text { Cidongke }\end{array}$ & Waterfall deriving from Cidongke river \\
\hline 13 & $\begin{array}{c}\text { Curug } \\
\text { Cigangsa } \\
\end{array}$ & $\begin{array}{l}\text { Waterfall firstly found near Gangsa } \\
\text { trees }\end{array}$ \\
\hline 14 & Curug Cikaso & $\begin{array}{l}\text { Waterfall firstly found many Kaso trees } \\
\text { around }\end{array}$ \\
\hline 15 & Curug Gentong & $\begin{array}{l}\text { Waterfall with clay bucket-like at the } \\
\text { bottom }\end{array}$ \\
\hline
\end{tabular}

Table 6. Geodiversity: Sightseeings' names and descriptions

\begin{tabular}{ccc}
\hline No & Names & Meaning \\
\hline 1 & Panenjoan & $\begin{array}{c}\text { Sightseeing spot from the top to below } \\
\text { area with landscape view }\end{array}$ \\
\hline 2 & $\begin{array}{c}\text { Puncak } \\
\text { Jeungjing }\end{array}$ & $\begin{array}{c}\text { Sightseeing spot with many Jeungjing } \\
\text { trees around the geosite }\end{array}$ \\
\hline 3 & Puncak Darma & $\begin{array}{c}\text { Sightseeing spot named with Buddhism } \\
\text { term Darma }\end{array}$ \\
\hline 4 & $\begin{array}{c}\text { Mega } \\
\text { Amphitheater }\end{array}$ & $\begin{array}{c}\text { A natural big amphitheater with } \\
\text { landscape view around the geosite }\end{array}$ \\
\hline
\end{tabular}

In addition, alternative choices to visit are beaches in CPUGGp as mentioned in Table 7 with various and different scenes, physical characteristics and uniqueness of beaches that will be experienced during their nature adventures such as no $2,3,4,5,6,7,8,10,15,17,18,20$. In addition, there are some storytellings regarding the folklores in the past about the beach such as number $1,9,12,17,19,22,23$ and also geographical locations of the beach like $11,13,14$, and 16 . When visiting the beaches especially Cimaja Beach, tourism activities are not only viewing the scenes but also surfing since the beach is often chosen as the location for international surfing competition. 
Table 7. Geodiversity: Beaches' names and descriptions

\begin{tabular}{|c|c|c|}
\hline No & Names & Meaning \\
\hline 1 & $\begin{array}{c}\text { Pantai } \\
\text { Palangpang }\end{array}$ & $\begin{array}{c}\text { A beach with many woods and } \\
\text { bamboos crossed for making Bagang }\end{array}$ \\
\hline 2 & $\begin{array}{c}\text { Pantai } \\
\text { Cikeueus/Kesik }\end{array}$ & A beach with much sand spread \\
\hline 3 & Pantai Cikalapa & $\begin{array}{l}\text { A beach with many coconut trees } \\
\text { around }\end{array}$ \\
\hline 4 & $\begin{array}{c}\text { Pantai } \\
\text { Batununggul }\end{array}$ & A beach with a big bowing rock \\
\hline 5 & $\begin{array}{c}\text { Pantai } \\
\text { Legonpandan }\end{array}$ & Beach with grass and pandan overlay \\
\hline 6 & Pantai Cikepuh & $\begin{array}{l}\text { Beach with many Kepuh trees firstly } \\
\text { found }\end{array}$ \\
\hline 7 & $\begin{array}{l}\text { Pantai Ujung } \\
\text { Sodong }\end{array}$ & $\begin{array}{c}\text { Beach with overhanging rock on the } \\
\text { beach }\end{array}$ \\
\hline 8 & Pantai Cibulakan & $\begin{array}{l}\text { A beach with boiling water like in } \\
\text { the seawater }\end{array}$ \\
\hline 9 & Pantai Citirem & Beach with many oysters in the past \\
\hline 10 & $\begin{array}{l}\text { Pantai Ombak } \\
\text { Tujuh }\end{array}$ & $\begin{array}{l}\text { Beach with many waves coming in } \\
\text { turn as if there are } 7 \text { waves }\end{array}$ \\
\hline 11 & $\begin{array}{c}\text { Pantai } \\
\text { Pangumbahan }\end{array}$ & $\begin{array}{c}\text { Beach located in Pangumbahan } \\
\text { Village Sukabumi }\end{array}$ \\
\hline 12 & Pantai Cibuaya & $\begin{array}{l}\text { Beach with a story of crocodile } \\
\text { finding in the past }\end{array}$ \\
\hline 13 & $\begin{array}{l}\text { Pantai Ujung } \\
\text { Genteng }\end{array}$ & $\begin{array}{c}\text { Beach located in Ujung Genteng } \\
\text { district }\end{array}$ \\
\hline 14 & $\begin{array}{l}\text { Pantai Muara } \\
\text { Cikarang }\end{array}$ & Beach near the Cikarang river \\
\hline 15 & $\begin{array}{l}\text { Pantai Karang } \\
\text { Bolong }\end{array}$ & Beach with hole rock as its features \\
\hline 16 & $\begin{array}{c}\text { Pantai } \\
\text { Palabuhanratu }\end{array}$ & Beach in Palabuhanratu city \\
\hline 17 & Pantai Cimaja & $\begin{array}{l}\text { Beach with many Maja trees in the } \\
\text { past time }\end{array}$ \\
\hline 18 & $\begin{array}{l}\text { Pantai Karang } \\
\text { Hawu }\end{array}$ & $\begin{array}{l}\text { Beach with a Sundanese traditional } \\
\text { wood stove }\end{array}$ \\
\hline 19 & Pantai Loji & $\begin{array}{l}\text { Beach near the Loji building in the } \\
\text { past time }\end{array}$ \\
\hline 20 & $\begin{array}{l}\text { Pantai Karang } \\
\text { Embe }\end{array}$ & Beach with rock like a sheep \\
\hline 21 & Pantai Mina Jaya & Beach used for fish boat harbor \\
\hline 22 & Pantai Cikadal & $\begin{array}{l}\text { Beach firstly found many lizards in } \\
\text { the past time }\end{array}$ \\
\hline 23 & Pantai Citepus & $\begin{array}{l}\text { Beach with many Tepus trees in the } \\
\text { past time }\end{array}$ \\
\hline
\end{tabular}

Then, visiting beaches will be completed with enjoying various kinds of stones with their geological distinctions and picturesque since most of the stone sites is on the small islands close to the coastal areas and some other ones nearby. As listed in Table 8, visitors will meet a large number of stones with their unique physical form identical to animals such as Batu Badak, Batu Buaya, Batu Kerbau, Batu Kodok, Batu Punggung Naga, Batu Komodo, Batu Kura-Kura and the ones forming particular motives like Batu Catur, Batu Pagar, Batu Batik, Batu Bedhil, Batu Nunggul and Batu Kasur.

Then, together with exploring beaches and stones on foot, tourists are recommended to continue the adventures by visiting some small islands, as seen in Table 9, using boats to have coastal activities such as snorkeling, swimming, and enjoying the uniqueness of each island. Various characteristics of the island are so interesting that they have different characteristics such as biodiversity in the islands such as Pulau Manuk, Pulau Cibanteng, then their unique appearances as Pulau Karang Daeu, Gunung Beas, Gunung Sungging. Furthermore, visitors are able to enjoy storytelling about the islands such as Pulau Mandra and Pulau Kunti. Their storytellings have close relations with their place name histories, namely the reasons of their namings in the past time. Furthermore, their namings contain local wisdoms and interesting values for the tourists.

Table 8. Geodiversity: Stones' names and descriptions

\begin{tabular}{|c|c|c|}
\hline No & Names & Meaning \\
\hline 1 & Batu Catur & Stone like chess board \\
\hline 2 & Batu Pagar & Stone like fence \\
\hline 3 & Batu Badak & Stone like rhinoceros \\
\hline 4 & Batu Buaya & Stone like crocodile \\
\hline 5 & Batu Kerbau & Stone like buffalo \\
\hline 6 & Batu Kodok & Stone like frog \\
\hline 7 & Batu Nunggul & $\begin{array}{c}\text { Beach with giant rock } \\
\text { standing on the } \\
\text { seawater }\end{array}$ \\
\hline 8 & $\begin{array}{c}\text { Batu Punggung } \\
\text { Naga }\end{array}$ & $\begin{array}{c}\text { Stone like the back of } \\
\text { dragon }\end{array}$ \\
\hline 9 & Batu Batik & $\begin{array}{c}\text { Stone with Batik } \\
\text { fabric motive }\end{array}$ \\
\hline 10 & Batu Komodo & $\begin{array}{c}\text { Stone like Giant } \\
\text { Lizard }\end{array}$ \\
\hline 11 & Batu Kura-Kura & Stone like turtle \\
\hline 12 & Taman Batu & Stone park \\
\hline 13 & Batu Bedhil & Stone like riffle \\
\hline 14 & Batu Kasur & Stone like mat \\
\hline
\end{tabular}

Table 9. Geodiversity: Small islands' names, and descriptions

\begin{tabular}{ccc}
\hline No & Names & Meaning \\
\hline 1 & $\begin{array}{c}\text { Pulau Karang } \\
\text { Daeu }\end{array}$ & Rock island in a far distance \\
\hline 2 & Pulau Mandra & $\begin{array}{c}\text { Small island to take break while } \\
\text { fishing }\end{array}$ \\
\hline 3 & Gunung Beas & Small island with rice-like sands \\
\hline 4 & Gunung Sungging & $\begin{array}{c}\text { Small island looks like a decorative } \\
\text { rocks }\end{array}$ \\
\hline 5 & Pulau Manuk & Small island with many birds \\
\hline 6 & Pulau Kunti & Small island with hollow rocks \\
\hline 7 & Pulau Cibanteng & Small island for buffalo conservation \\
\hline
\end{tabular}

Getting off the boat and stepping on some small islands, the tourists are presented several geosites in the form of caves, seen in Table 10, with biodiversity characteristics such as due to many bats in the cave, then it is named using Sundanese word "Goa Lalay" which means bat. On the other hand, the caves are also named due to their forms and typical appearances such as "Goa Sodong Parat" since it is sharp protruding cave and "Goa Kunti" due to its form as hollow rock looks like the back of local female ghost in traditional storytellings Kuntilanak.

Table 10. Geodiversity: Caves' names and descriptions

\begin{tabular}{ccc}
\hline No & Names & Meaning \\
\hline 1 & Goa Lalay & Cave full of bats \\
\hline 2 & Goa Sodong Parat & Cave under the overhanging rock \\
\hline 3 & Goa Kunti & Small cave with hollow rock \\
\hline
\end{tabular}

Having explored the geological tourism spots of CPUGGp, the adventure is continued with enjoying biodiversity sites. In the agroindustry spots, visitors can pick up and taste the local fruits like Durians and Dragon fruits from the garden. Then, in the process of local brown sugar production, the tourists are 
also given opportunity to be involved in cooking and pressing the sugar traditionally. The biodiversity products are, as listed in Table 11, also able to be taken away as local product gifts for tourists.

Table 11. Biodiversity: Agriculture's names and descriptions

\begin{tabular}{ccc}
\hline No & Names & Meaning \\
\hline 1 & Kebun Teh & Tea plantation \\
\hline 2 & Perkebunan Buah Naga & Dragon fruit farming \\
\hline 3 & Beas Hideung & Black rice farming \\
\hline 4 & Perkebunan & Durian and various fruits \\
& Maranginan & Farming \\
\hline 5 & Gula Kelapa & Brown sugar production \\
\hline 6 & Perkebunan Cengkeh & Clove Farming \\
\hline 7 & Hutan Ciletuh & Flora and Fauna Conservation \\
\hline 8 & Hanjeli & Alternative food resource \\
\hline 9 & Sorgum & Alternative food resource \\
\hline
\end{tabular}

\subsubsection{Biodiversity}

Furthermore, the biodiversities of CPUGGp are also enriched with specific grain products uncommonly found in other areas, namely black rice, Hanjeli and Sorgum. Not only land biodiversity, but also there are many seafood plates served from Palangpang fish port with fresh fish from the sea. Not only for local consumption, the fishery products especially eel and shrimp have become export commodities and traded to international market such as Europe and Japan, while the local fish are sold in local market. These fishery and marine potencies can be found in Table 12 .

Table 12. Biodiversity: Fisheries' names and descriptions

\begin{tabular}{ccc}
\hline No & Names & Meaning \\
\hline 1 & Budidaya Belut & Eel breeding \\
\hline 2 & Budidaya Udang & Shrimp Farming \\
\hline 3 & Pelelangan Ikan & Fishport \\
\hline
\end{tabular}

The other biodiversity products in CPUGGp are, listed in Table 13, in the form of wild reserve conservations where the tourists are finding many local floras and faunas and enjoying snorkling and white sand beach.

Table 13. Biodiversity: Conservations' names and descriptions

\begin{tabular}{ccc}
\hline No & Names & Meaning \\
\hline 1 & Cagar Alam Tangkuban Parahu & Nature Conservation \\
\hline 2 & Cagar Alam Cibanteng & Nature Conservation \\
\hline 3 & Budidaya Anggrek & Orchid Farming \\
\hline
\end{tabular}

In agrotourism potentials, CPUGGp is so strategic for developing agricultural products such as rice fields that can be used for the cultivation of local and aforementioned unique black rice and tropical fruits as well as medicinal plant ingredients i.e. cloves, red ginger, onions, fragrant lemongrass, turmeric, etc. For tourism activities, this biodiversity gives a memorable adventure tourism not only seeing them but also doing the local people daily activities in the farm and learning their philosophical and smart farming.

\subsubsection{Culture}

As the typical characteristics of geopark, culture becomes important sites that visitors should be experienced. There are two kinds of cultural heritages in CPUGGp, namely tangible and intangible ones. These sites enable the tourists to experience the local indigenous cultures and enjoy their daily lives which are rich of local genius and traditional ways of life. They always relate their activities and rituals with nature and base their daily routines for harmony. Potential cultural heritage is also found in this geopark area such as megalithic sites, colonial relics, as well as several traditional villages of Kasepuhan Banten Kidul, including the village of Cipta Gelar, Sinar Resmi, and Ciptamulya. They have special traditional ceremonies held in particular moments like harvesting, planting, and other divine services. The local people and their tangible cultures are listed in the following Table 14

Table 14. Culture: Tangible heritages' names and descriptions

\begin{tabular}{|c|c|c|}
\hline No & Names & Meaning \\
\hline 1 & Vihara Dewi Kwan Im & Prayer site of Buddhism \\
\hline 2 & Kasepuhan Sinar Resmi & $\begin{array}{l}\text { Local indigenous people and } \\
\text { culture }\end{array}$ \\
\hline 3 & Kasepuhan Cipta Mulya & $\begin{array}{c}\text { Local indigenous people and } \\
\text { culture }\end{array}$ \\
\hline 4 & Kasepuhan Cipta Gelar & $\begin{array}{c}\text { Local indigenous people and } \\
\text { culture }\end{array}$ \\
\hline 5 & Situs Pangguyangan & $\begin{array}{c}\text { Traditional and local belief } \\
\text { site }\end{array}$ \\
\hline 6 & Situs Cangkuk & $\begin{array}{l}\text { Traditional and local belief } \\
\text { site }\end{array}$ \\
\hline 7 & $\begin{array}{l}\text { Kampung Budaya } \\
\text { Cipondoh }\end{array}$ & $\begin{array}{c}\text { Traditional art and culture } \\
\text { community }\end{array}$ \\
\hline 8 & $\begin{array}{l}\text { Paguyuban Lahan } \\
\text { Parahyangan }\end{array}$ & $\begin{array}{l}\text { Traditional art and culture } \\
\text { community }\end{array}$ \\
\hline 9 & Panglayungan Budaya & $\begin{array}{c}\text { Traditional art and culture } \\
\text { community }\end{array}$ \\
\hline 10 & Paguyuban Pakidulan & $\begin{array}{l}\text { Traditional and local } \\
\text { community }\end{array}$ \\
\hline
\end{tabular}

Furthermore, visitors have many choices in exploring the cultures in CPUGGp since there are other shapes of intangible ones in the form of traditional arts such as dancing, singing, music, and ceremonies. Some of the art performances are held routinely in the afternoon or evening every day in several communities namely in Panglayungan Budaya Parahyangan that is preserving the original and vintage traditional art old Sundanese art performances and cultures. On the other hand, the other community namely Paguyuban Lahan Parahyangan is also presenting many local art performances and cultures adapted from some contemporary arts in order to facilitate the creativities of local young generations in Jampang area known as Waluran.

Table 15. Culture: Intangible heritages' names and descriptions

\begin{tabular}{ccc}
\hline No & Names & Meaning \\
\hline 1 & Syukuran Nelayan Ciwaru & Traditional ceremony \\
\hline 2 & Kuda Lumping & Traditional art \\
\hline 3 & Cepetan & Traditional art \\
\hline 4 & Seni Cepet & Traditional art \\
\hline 5 & Seni Gondang & Traditional art \\
\hline 6 & Seni Liliuran & Traditional art \\
\hline 7 & Seni Ngahiras & Traditional art \\
\hline 8 & Seni Beluk & Traditional art \\
\hline 9 & Seni Dogdog lojor & Traditional art \\
\hline 10 & Seni Sora Awi & Traditional art \\
\hline 11 & Syukuran Nelayan Cisolok & Traditional Ceremony \\
\hline 12 & Syukuran Nelayan Minajaya & Traditional Ceremony \\
\hline 13 & Syukuran Nelayan Palabuhanratu & Traditional Ceremony \\
\hline
\end{tabular}


The traditional arts and ceremonies, as mentioned in Table 15 , are held in different times i.e. once a year as annual events involving many local people to contribute in the annual events and daily ones in their own community both as tourism attractions and rituals. The geosite data based on the observation and literature discussed above are used to confirm the data based on survey and descriptive statistics.

Based on the purposive random sampling survey, the dependent variable on understanding of the respondents towards the CPUGGp's tourism characteristics are summed up in the following Table 16.

Table 16. CPUGGp's tourism description

\begin{tabular}{|c|c|c|}
\hline Code & Existing Condition of CPUGGp & Responses \\
\hline AQ1 & $\begin{array}{l}\text { CPUGGp is rich of geodiversity, } \\
\text { biodiversity, and cultural heritages as } \\
\text { mentioned in Table } 5-15 \text { which enables } \\
\text { tourists to have quality adventure tourism. }\end{array}$ & $\begin{array}{c}1: 0 \% \\
2: 0 \% \\
3: 3.3 \% \\
4: 16.7 \% \\
5: 80 \%\end{array}$ \\
\hline AQ2 & $\begin{array}{l}\text { It is clearly listed the geoheritages, } \\
\text { biodiversity and cultural heritage which } \\
\text { are so distinctive that are interesting to be } \\
\text { blended as adventure tourism activities. }\end{array}$ & $\begin{array}{c}1: 1.7 \% \\
2: 0 \% \\
3: 6.7 \% \\
4: 13.3 \% \\
5: 78.3 \% \\
\end{array}$ \\
\hline AQ3 & $\begin{array}{c}\text { Table } 11,12 \text { and } 13 \text { are presenting not } \\
\text { only agricultural activities to plant daily } \\
\text { need such as rice and corn but also special } \\
\text { black rice, Hanjeli, and plantation on tea, } \\
\text { fruit breeding. The farmers are developing } \\
\text { not only agricultural products but also } \\
\text { fishery and orchids. }\end{array}$ & $\begin{array}{l}1: 1.7 \% \\
2: 1.7 \% \\
3: 13.3 \% \\
4: 21.7 \% \\
5: 61.7 \%\end{array}$ \\
\hline AQ4 & $\begin{array}{l}\text { The visitors are able to enjoy all tourism } \\
\text { sites not only something to see, something } \\
\text { to do but also something to learn in nature } \\
\text { destination, culture and creativity } \\
\text { tourisms. }\end{array}$ & $\begin{array}{c}1: 0 \% \\
2: 1.7 \% \\
3: 10 \% \\
4: 28.3 \% \\
5: 60 \% \\
\end{array}$ \\
\hline AQ5 & $\begin{array}{c}\text { Table } 11,12,13,14 \text { and } 15 \text { are giving } \\
\text { various creativity with different local } \\
\text { products starting from agroindustry, } \\
\text { fishery, as well as tangible and intangible } \\
\text { cultures. }\end{array}$ & $\begin{array}{c}1: 0 \% \\
2: 8.3 \% \\
3: 11.7 \% \\
4: 26.7 \% \\
5: 53.3 \% \\
\end{array}$ \\
\hline AQ6 & $\begin{array}{l}\text { CPUGGp is developing local products } \\
\text { based on agriculture such as Sorgum, } \\
\text { Hanjeli, Orchids, Coffee, Fruits, Black } \\
\text { rice, Raflessia, red ginger, honey, palm } \\
\text { sugar, Virgin Coconut oil, etc. }\end{array}$ & $\begin{array}{l}1: 0 \% \\
2: 5 \% \\
3: 10 \% \\
4: 30 \% \\
5: 55 \% \\
\end{array}$ \\
\hline
\end{tabular}

From the survey, it is identified that the majority of respondent gives positive responses on the descriptions of the CPUGGp's sites. 96.7\% agrees that CPUGGp fits with adventure tourism, then $91.6 \%$ agrees with CPUGGp as a blend of nature, culture, and creativity tourism. Related to the existence of micro SMSs in CPUGGp, 83.4\% respondents gives positive responses and $88.3 \%$ is given for high quality tourism experiences. Meanwhile, $80 \%$ agrees that CPUGGp has local products and creative economics, then local products based on nature potencies gets $85 \%$. Based on the Likert scale above, it can be calculated that the descriptive percentage is:

$$
\begin{aligned}
P & =\frac{\sum X}{n} \\
X & =\frac{525}{6} \\
X & =87.5
\end{aligned}
$$

Therefore, based on the percentage above, it can be described that respondents agree with CPUGGp's tourism destinations that enable visitors to have quality adventure tourism with supports of geodiversity and biodiversity, as well as cultural heritages.

\subsection{Adaptability of CPUGGp towards COVID-19 Pandemic}

CPUGGp is an area that is rich of nature, environment, social and culture that are wrapped in a wide and open spaces so that it enables to avoid mass tourism, in that case such various destinations tend to give quality tourism activities regarding nature, ecotourism, wellness and adventure which fit with the pandemic situation. It can be analyzed and

\begin{tabular}{|c|c|c|}
\hline Code & Existing Condition of CPUGGp & Responses \\
\hline BQ1 & $\begin{array}{l}\text { CPUGGp is an open space area with } \\
\text { hundreds of kilometres in width so that it } \\
\text { enables to avoid a mass gathering and } \\
\text { comply physical and social distancing } \\
\text { among the visitors. Furthermore, }\end{array}$ & $\begin{array}{c}1: 1.7 \% \\
2: 5 \% \\
3: 16.7 \% \\
4: 26.7 \% \\
5: 50 \% \\
\end{array}$ \\
\hline BQ2 & $\begin{array}{l}\text { The principle health protocol based on } \\
\text { COVID-19 pandemic such as using mask, } \\
\text { washing hands, and social distancing can } \\
\text { be complied in the CPUGGp. } \\
\text { Furthermore, most of the destinations are } \\
\text { outside the room hence it is an open air } \\
\text { and quite safe for physical distancing. }\end{array}$ & $\begin{array}{l}1: 1.7 \% \\
2: 3.3 \% \\
3: 6.7 \% \\
4: 35 \% \\
5: 53.3 \%\end{array}$ \\
\hline BQ3 & $\begin{array}{l}\text { CPUGGp is a wide area with various and } \\
\text { distant destination one another so that it } \\
\text { enables to physical and social distancing } \\
\text { during the pandemic. Moreover, CPUGGp } \\
\text { is highly approriate for isolation and } \\
\text { recovery for the infected patients. }\end{array}$ & $\begin{array}{c}1: 1.7 \% \\
2: 3.3 \% \\
3: 11.7 \% \\
4: 28.3 \% \\
5: 55 \%\end{array}$ \\
\hline BQ4 & $\begin{array}{l}\text { A large area with various geosites is able } \\
\text { to accommodate limited number of visitors } \\
\text { during pandemic. }\end{array}$ & $\begin{array}{c}1: 0 \% \\
2: 0 \% \\
3: 8.3 \% \\
4: 36.7 \% \\
5: 55 \% \\
\end{array}$ \\
\hline BQ5 & $\begin{array}{l}\text { All destinations in CPUGGp are outside } \\
\text { the room and open space tourism spots } \\
\text { which are open air sites. }\end{array}$ & $\begin{array}{c}1: 0 \% \\
2: 0 \% \\
3: 1.7 \% \\
4: 10 \% \\
5: 88.3 \% \\
\end{array}$ \\
\hline BQ6 & $\begin{array}{c}\text { During pandemic, local people develop } \\
\text { some local food and farming such as red } \\
\text { ginger, honey as the resilience effort } \\
\text { during pandemic. }\end{array}$ & $\begin{array}{c}1: 0 \% \\
2: 0 \% \\
3: 8.3 \% \\
4: 30 \% \\
5: 61.7 \% \\
\end{array}$ \\
\hline
\end{tabular}
confirmed in the following Table 17.

Table 17. CPUGGp and COVID-19 Pandemic

Having tourism activities in CPUGGp highly enable the visitors to have physical and social distancings since the area of CPUGGp is so large and the destinations are spotted in many different areas that the crowded situation and overtourism are avoidable. Since there are various kinds of tourism activities, CPUGGp also gives opportunity to the travellers namely to reconceptualize adventure from common nature to the one added with cultural activities as the part of whole adventure trip, travel that blends natural, social and cultural experiences. As world class geopark, CPUGGp has many destinations and offers ecotourism products based on the local natural and cultural heritages which do not contribute to overcrowding but offering high-quality experiences for tourists.

In this global crisis, the nature is refreshed from pollution, the economy is empowered with local products such as 
agriculture, tea plantation and fishery, then the social and culture are strengthened with togetherness of facing the pandemic and reactivating the local arts during the pandemic. Furthermore, the visitors are still able to step onto the tourism sites with health protocols and guarantees of cleanliness, health, safety, and environment (CHSE) and enjoy the various kinds of tourism activities.

From the Likert-scales, it is identified that $76.7 \%$ respondent said that there is no tourist crowd in CPUGGp and $88.3 \%$ respondent agreed with the ability of complying health protocols when the tourists visiting CPUGGp's sites. Then $83.3 \%$ respondent agreed that the tourists are able to have social distancing, $91.7 \%$ respondent declared that CPUGGp is able to accommodate the visitors according to COVID-19 health protocols, $98.3 \%$ agreed that CPUGGp is an open space tourism, and $91.7 \%$ agreed that during COVID-19 pandemic there is not nature exploitation.

$$
\begin{gathered}
P=\frac{\sum X}{n} \\
X=\frac{530}{6} \\
X=88.3 \%
\end{gathered}
$$

Based on the calculation, it can be underlined that the descriptive percentage as much as $88.3 \%$, means that respondents strongly agree with CPUGGp's ability to make adaptation towards COVID-19 tourism.

\subsection{Applicability of sustainable tourism in CPUGGp}

Regarding to sustainable tourism, CPUGGp has balances on the environment, economy, social and culture which are in line with the challenge after COVID-19 pandemic namely tourism to heal the natural world. CPUGGp also concerns to resilience and sustainability since it has ecological, biological, social, and cultural resources to survive during pandemic which are presented in the following Table 18 analyzing the applicability of sustainable tourism in CPUGGp.

\begin{tabular}{|c|c|c|}
\hline \multicolumn{3}{|c|}{$\begin{array}{l}\text { truly empower the local economic and } \\
\text { people. }\end{array}$} \\
\hline CQ5 & $\begin{array}{l}\text { All tables from Table } 5-15 \text { show that } \\
\text { tourism activities in CPUGG closely } \\
\text { relate to nature and culture potencies, and } \\
\text { people resources and creativities. } \\
\text { Therefore, those activities give impacts } \\
\text { towards local people. }\end{array}$ & $\begin{array}{c}\text { 1: } 0 \% \\
2: 0 \% \\
3: 0 \% \\
4: 33.3 \% \\
5: 66.7 \%\end{array}$ \\
\hline CQ6 & $\begin{array}{l}\text { This statement is to confirm the previous } \\
\text { statement with code number QA1 that } \\
\text { CPUGGp is providing adventure } \\
\text { experience which is still in line with the } \\
\text { following statement QA2 that CPUGGp } \\
\text { blends the nature, culture and creativity } \\
\text { tourisms. }\end{array}$ & $\begin{array}{c}1: 0 \% \\
2: 1.7 \% \\
3: 3.3 \% \\
4: 25 \% \\
5: 70 \%\end{array}$ \\
\hline CQ7 & $\begin{array}{l}\text { As an open space, wide area, and distant } \\
\text { position among the geosites, CPUGGp has } \\
\text { capacity to accommodate many visitors } \\
\text { with COVID-19 pandemic health } \\
\text { protocols. }\end{array}$ & $\begin{array}{c}1: 0 \% \\
2: 0 \% \\
3: 8.3 \% \\
4: 33.3 \% \\
5: 58.3 \%\end{array}$ \\
\hline CQ8 & $\begin{array}{l}\text { The geographical condition of CPUGGp } \\
\text { enables to control the over tourism } \\
\text { especially by visitor management system } \\
\text { to distribute the visitor position among the } \\
\text { existing geosites spread in wide geoarea. }\end{array}$ & $\begin{array}{c}1: 0 \% \\
2: 1.7 \% \\
3: 10 \% \\
4: 30 \% \\
5: 58.3 \% \\
\end{array}$ \\
\hline CQ9 & $\begin{array}{c}\text { The accessibility of CPUGGp which } \\
\text { cannot be accessed with big vehicles like } \\
\text { bus recommend the visitors to use small } \\
\text { vehicles such as MPV or minibus. } \\
\text { Therefore, group tourists enable to avoid } \\
\text { mass tourism. }\end{array}$ & $\begin{array}{c}1: 0 \% \\
2: 0 \% \\
3: 13.3 \% \\
4: 30 \% \\
5: 56.7 \%\end{array}$ \\
\hline CQ10 & $\begin{array}{l}\text { Tourism in geopark area especially } \\
\text { CPUGGp is developed with the concept of } \\
\text { sustainable tourism, hence its activities } \\
\text { and development are oriented in nature } \\
\text { and environment conservations. }\end{array}$ & $\begin{array}{c}\text { 1: } 0 \% \\
2: 0 \% \\
3: 10 \% \\
4: 20 \% \\
5: 70 \% \\
\end{array}$ \\
\hline CQ11 & $\begin{array}{l}\text { The sustainable development concept as } \\
\text { the foundation of the tourism development } \\
\text { in CPUGGp focuses not only in the nature } \\
\text { and environment aspects but also to } \\
\text { economic sector in which labor and local } \\
\text { people empowerment are impacted by the } \\
\text { tourism activities in CPUGGp. The } \\
\text { increasing number of tourism sector will } \\
\text { recruit more human resources especially } \\
\text { the local people }\end{array}$ & $\begin{array}{c}1: 0 \% \\
2: 0 \% \\
3: 8.3 \% \\
4: 25 \% \\
5: 66.7 \%\end{array}$ \\
\hline CQ12 & $\begin{array}{l}\text { The developing of tourism activities will } \\
\text { influence the economic sector, the longer } \\
\text { the visitors stay in CPUGGp, the more } \\
\text { money to spend by them which impact to } \\
\text { local business income }\end{array}$ & $\begin{array}{c}1: 0 \% \\
2: 0 \% \\
3: 1.7 \% \\
4: 28.3 \% \\
5: 70 \%\end{array}$ \\
\hline CQ13 & $\begin{array}{l}\text { The strengthenings of the environment, } \\
\text { local economic and income will give } \\
\text { impacts to the social security. The tourism } \\
\text { activities will improve the social activities } \\
\text { and collaborations. }\end{array}$ & $\begin{array}{c}1: 0 \% \\
2: 0 \% \\
3: 1.7 \% \\
4: 31.7 \% \\
5: 66.7 \% \\
\end{array}$ \\
\hline CQ14 & $\begin{array}{l}\text { In line with environment, social, and } \\
\text { economic empowerments, local arts and } \\
\text { cultures are also influenced by the tourism } \\
\text { activities. In quality tourism during and } \\
\text { after pandemic, the tourists visit CPUGGp } \\
\text { are not only for nature but also for culture } \\
\text { experience. Table } 13 \text { and } 14 \text { are some } \\
\text { existing arts and cultures that the visitors } \\
\text { can find during their visits to CPUGGp. }\end{array}$ & $\begin{array}{c}1: 0 \% \\
2: 0 \% \\
3: 1.7 \% \\
4: 33.3 \% \\
5: 65 \%\end{array}$ \\
\hline
\end{tabular}

Table 18. CPUGGp and sustainable tourism

\begin{tabular}{ccc}
\hline Code & Existing Condition of CPUGGp & Responses \\
\hline & & $1: 0 \%$ \\
CQ1 & From Tables 5-11, CPUGGp has a large & $2: 0 \%$ \\
& number of nature destinations. & $3: 0 \%$ \\
& & $4: 3.3 \%$ \\
& & $5: 96.7 \%$ \\
\hline & Tables 14 are some existing communities & $1: 0 \%$ \\
in CPUGGp with their conservation & $3: 0 \%$ \\
& activities in either nature or local culture. & $4: 23.3 \%$ \\
& & $5: 68.3 \%$ \\
\hline \multirow{4}{*}{ Table 14 shows the tangible cultural } & $1: 0 \%$ \\
& heritages of CPUGGp existing in some & $2: 0 \%$ \\
villages in geoarea of CPUGGp, while & $3: 1.7 \%$ \\
Table 15 presents the intangible cultural & $4: 20 \%$ \\
& heritages of CPUGGp that are preserved & $5: 78.3 \%$ \\
& by the local people and communities & \\
& around its geoarea. & $1: 0 \%$ \\
& The economic empowerment of the & $2: 0 \%$ \\
CQ4 & $3: 5 \%$ \\
& 11, 12, and 13 which involve communities & $4: 35 \%$ \\
in CPUGGp such as PAPSI, PALAPAH, & $5: 60 \%$ \\
& Panglayungan Budaya, Kasepuhan Cipta &
\end{tabular}

Looking through the results of survey in variable $\mathrm{C}$ above in which $100 \%$ respondent stated that CPUGGp is identical to nature tourism and $91.6 \%$ agreed with the positive contribution of the local communities towards geopark and 
tourism in CPUGGp which has unique cultural heritages, confirmed by $98.3 \%$ respondent and empowers local economy as stated by $95 \%$ respondents. Furthermore, $100 \%$ respondents agreed with function, beneficiaries and advantages for local people given CPUGGp. Regarding, tourism activities, 95\% respondent confirmed that tourism experience is interesting and $91.6 \%$ respondent agreed for capability of CPUGGp to accommodate the visitors properly with $88.3 \%$ respondent said that mass tourism can be avoided and in the form of visitor group as much as $86.7 \%$. In addition, $90 \%$ respondent believed with nature conservation occurring in CPUGGp together with opening job opportunities for local people as much as $91.7 \%$ hence it is able to improve the local income as stated by $98.3 \%$ respondent as well as $98.3 \%$ agreed with the improvement of local social welfare. Lastly, it is identified that 98.3 respondent confirmed that CPUGGp gives positive impact towards local cultures and arts.

$$
\begin{gathered}
P=\frac{\sum X}{n} \\
X=\frac{1323.1}{14} \\
X=94.5
\end{gathered}
$$

Totally, based on the percentage, it can be described that most of the respondent, as much as $94.5 \%$, strongly agree that CPUGGp is in accordance with sustainable tourism.

\subsection{Brand association of CPUGGp}

Geopark is about territory with its special characteristics and various resources for education, economy, and conservation. CPUGGp has territorial identity that this geopark is located in a particular area of Sukabumi Regency, West Java Province Indonesia since the place names of the sites describing the landscape of CPUGGp such as beach, highland, coastal area, etc. and their interaction with the local people, values, cultures and wisdoms. Ciletuh and Palabuhanratu are two important areas of Sukabumi Regency as the home of CPUGGP. On the other hand, the label of UNESCO Global Geopark gives identification that this geopark has global or world class geodiversities, biodiversities and cultural heritages. Therefore, looking at and understanding the name of CPUGGp can bring the tourists as consumers to identify that CPUGGp is the correct product of tourism to purchase in the COVID-19 pandemic since the CPUGGp communicates the types and characteristics of its tourism destinations namely geodiversities, biodiversities, as well as cultural sites. In addition, it also communicates the location of the nature tourism objects and destinations which give positive association in resilient tourism during and after pandemic. The people do not depend on the nature as tourism destination thoroughly but they are able to optimize the nature as agriculture potentials. Illustration of the brand association can be clearly seen in Figure 2.

As a brand, CPUGGp is also associated with a sustainable tourism product for its relations to environment or nature conservation, social and culture preservation, as well as economic empowerment. Due to its UNESCO attribute, CPUGGp has international quality tourisms which can be proved with their existences in UNESCO's promotional media. It has distinctive features of global class tourism destinations and world-widely recognized as geotourism. The world class quality is seen from the names of tourism sites. Regarding to particular situation especially COVID-19 pandemic, brand of CPUGGp is the right place for adventure tourism activities exploring nature, culture and people in CPUGGp during pandemic.

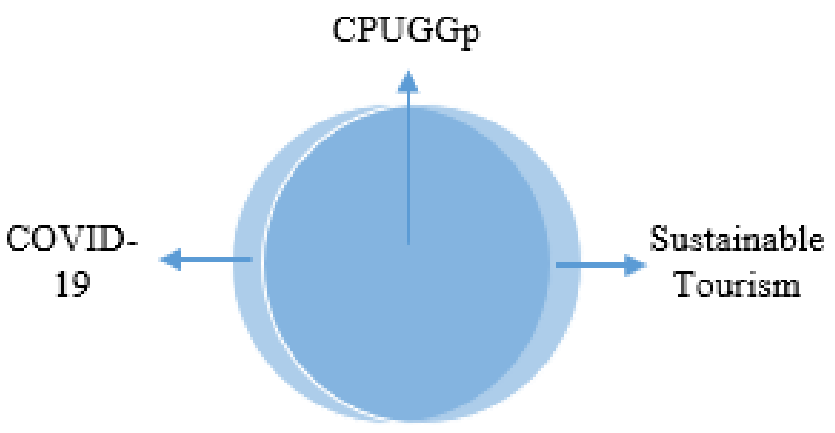

Figure 2. Brand association of CPUGGp towards COVID-19 pandemic and sustainable tourism

\section{CONCLUSIONS}

COVID-19 pandemic does not only cause a bad impact for tourism industry but also gives positive opportunities for tourism destinations to have a recovery. Based on the site names, CPUGGp is an appropriate destination because of its tourism attractions including geotourism, cultural tourism, agrotourism, adventure tourism, and marine tourism in accordance with tourism activities and recovery during and after COVID-19 pandemic. From the results of survey, it can be concluded that the tourism destinations in CPUGGp is associated to quality tourism products that are related with COVID-19 pandemic. As an open space destination, CPUGGp is able to meet with the health protocol that should be complied during and after pandemic. From these points, it can be summed up that CPUGGp as tourism product has a strong association with a proper tourism destination that are recommended to visit in the pandemic situation.

Regarding to sustainable tourism concepts covering nature and its environment, people and their social and culture, as well as their economic empowerment, CPUGGp are highly proven by the respondents' statements with $94.5 \%$ is strongly agree with the sustainability occurring in CPUGGp. The UNESCO Global Geopark's attribute gives a warranty that CPUGGp has quality tourism destinations and activities which give benefits not only for the local society but also for the international tourists as consumers. The distinctive and various tourism sites enable visitors to do many tourism activities from something to see, to do, to learn as well as to experience as the results of adventure tourisms that are able to increase the happiness, then the happiness can improve the immunity which has good effect to fight against the COVID19 infection. The strongly agree responses of the respondents in three variables namely geosites in CPUGGp and their tourism characteristics, adaptability of CPUGGp towards COVID-19 Pandemic as well as applicability of sustainable tourism in CPUGGp are the brand associations that CPUGGp is proper destinations to visit during the COVID-19 pandemic and good model of sustainable tourism during and after pandemic. 


\section{ACKNOWLEDGMENT}

This research is funded by Ministry of Education and Culture Republic of Indonesia under the Grant of Program Disertasi Dosen (2021). Such a great thank is also conveyed to CPUGGp management and some communities and people in CPUGGp area.

\section{REFERENCES}

[1] Chakraborty, I., Maity, P. (2020). COVID-19 outbreak: Migration, effects on society, global environment and prevention. Science of the Total Environment, 728: 138882. https://doi.org/10.1016/j.scitotenv.2020.138882

[2] WHO. (2020). Clinical Management of Severe Acute Respiration Infection When Novel Coronavirus (2019nCov) Infection is Suspected: Interim Guidance. World Health Organization.

[3] Krishnakumar, B., Sravendra, R. (2020). COVID-19 in India: Strategies to combat from combination threat of life and livelihood. Journal of Microbiology, 5(3): 389391. https://doi.org/10.1016/j.jmii.2020.03.024

[4] Arby, I. (2020). Indonesia hits the consecutive records highs in coronavirus. www.thejakartapost.com: https://www.thejakartapost.com/news/2020/09/24/indon esia-hits-consecutive-record-highs-in-coronaviruscases.html.

[5] Juliana, Parani, R., Sitorus, N.I.B., Pramono, R., Maleachi, S. (2021). Study of community-based tourism in the district of West Java. International Journal of Sustainable Development and Planning, 16(2): 277-285. https://doi.org/10.18280/ijsdp.160207

[6] Pamungkas, K., Sujatna, E., Heriyanto, Haron, R. (2020). Geotourism branding through the names of tourism destinations in UNESCO global geopark batur bali: Morphological and toponymic studies. Geojournal of Tourism and Gesites, 31(3): 966-971. https://doi.org/10.30892/gtg.31305-528

[7] Higgins-Desbiolles, F., Carnicelli, S., Krolikowski, C., Wijesinghe, G., Boluk, K. (2019). Degrowing tourism: Rethinking tourism. Journal of Sustainable Tourism, 27(12):

1926-1944. https://doi.org/10.1080/09669582.2019.1601732

[8] Jamal, T., Budke, C. (2020). Tourism in a world with pandemics: Local-global responsibility and action. Journal of Tourism Futures, 6(2): 181-188 https://doi.org/10.1108/JTF-02-2020-0014

[9] Nepal, S.K. (2020). Adventure travel and tourism after COVID-19 - business as usual or opportunity to reset? Tourism Geographies, 22(3): 646-650. https://doi.org/10.1080/14616688.2020.1760926

[10] Romagosa, F. (2020). The COVID-19 crisis: Opportunities for sustainable and proximity tourism. Tourism Geographies, 22(3): 690-694. https://doi.org/10.1080/14616688.2020.1763447

[11] Adiakurnia, M.I. (2018). Geopark Ciletuh Dapat Pengakuan UNESCO Global Geopark. https://travel.kompas.com/read/2018/04/17/172000427/ geopark-ciletuh-dapat-pengakuan-UNESCO-globalgeopark.

[12] Rosana, M.F. (2017). Universitas Padjadjaran. http://www.unpad.ac.id/wp-
content/uploads/2017/02/GNCP-toward-UGG_PeranUNPAD_07022017.pdf.

[13] Eber, S., World Wide Fund for Nature., \& Tourism Concern. (1992). Beyond the green horizon: Principles for sustainable tourism: A discussion paper commissioned from Tourism Concern by WWF UK. Godalming, Surrey: WWF UK.

[14] Butler, R.W. (1999). Sustainable tourism: A state-of-theart review. Tourism Geographies, 1(1): 7-25. https://doi.org/10.1080/14616689908721291

[15] Hall, C.M., Scott, D., Gössling, S. (2020). Pandemics, transformations and tourism: Be careful what you wish for. Tourism Geographies, 22(3): 577-589. https://doi.org/10.1080/14616688.2020.1759131

[16] Farsani, N., Coelho, C.C., de Carvalho, C. (2012). Geoparks and Geotourism: New Approaches to Sustainability for the 21 st Century. Florida, USA: Brown Walker Press.

[17] Yudhoyono, E.B., Siregar, H., Achsani, N.A., Irawan, T. (2021). The impact of tourism on the economy and community welfare in Labuan Bajo area, Indonesia. International Journal of Sustainable Development and Planning, $\quad 16(2)$ : 385-393. https://doi.org/10.18280/ijsdp.160219

[18] Cottrel, S., Vaske, J., Shen, F., Ritter, P. (2017). Resident Perception of Sustainable Tourism in Chingdugou China. Chongduguo China: Society and Natural Resources.

[19] Zouros, N., Martini, G. (2003). Introduction to the European geoparks network. 2nd International Symposium of Natural Monuments and Geological Heritage, Lesvos Greece: NHM Lesvos Petrified Forest, pp. 17-21.

[20] Bosak, K. (2016). Tourism, development and sustainability. In S. F. McCool, \& K. Bosak (Eds.). Reframing Sustainable Tourism, 33-44. https://doi.org/10.1007/978-94-017-7209-9

[21] Crossley, É. (2020). Ecological grief generates desire for environmental healing in tourism after COVID-19, Tourism Geographies, 22(3): 536-543. https://doi.org/10.1080/14616688.2020.1759133

[22] Saparov, A. (2003). The alteration of place names and construction of national identity in Soviet Armenia. Cahiers du Monde Russe, 44(1): 179-198. https://doi.org/10.4000/monderusse. 8604

[23] Helleland, B. (2012). Place names and identities. Oslo Studies in Language, 4(2): 95-116. https://doi.org/10.5617/osla.313

[24] Pamungkas, K., Abdulah, R. (2017). Linguistics-based pharmaceutical product naming methods: A morphological study on OTC medicine products in Indonesia. Asian Journal of Pharmaceutical and Clinical Research, 10(14): 108-122. https://doi.org/10.22159/ajpcr.2017.v10s2.19512

[25] Sujatna, E.T.S., Pamungkas, K., Heriyanto. (2021). Tourism sites naming in Ciletuh geopark: Toponymic and Morphological Studies. Kasetsart Journal of Social Sciences. $\quad 42(2021)$ : 147-152. https://doi.org/10.34044/j.kjss.2021.42.1.23

[26] Sujatna, E.T.S., Pamungkas, K., Heriyanto. (2019). Names as branding on nature tourism destinations in Pangandaran, Jawa Barat-Indonesia: A linguistic perspective. Pertanika Journal of Social Sciences \& Humanities, 27(2): 803-814. 
[27] Cretu, A., Brodie, R. (2007). The influence of brand image and company reputation where manufacturers market to small firms. Journal of Industrial Marketing Management, 36(2):

230-240. https://doi.org/10.1016/j.indmarman.2005.08.013

[28] Jamaluddin, M., Hanafiah, M., Zulkifly, M. (2013). Customer - based psychology branding. Procedia: Social and Behavior Sciences, 105(3): 772-780. https://doi.org/10.1016/j.sbspro.2013.11.080
[29] David, A. (2002). Building a Strong Brand. Sydney: Simon Schuster.

[30] Sugiarto, D., Hendratono, T., Sudibyo. (2015) Metodologi Penelitian Hospitaliti dan Pariwisata. Tangerang: PT. Matana Publishing Utama.

[31] Sugiyono. (2017). Metode Penelitian Pendidikan Pendekatan Kuantitatif, Kualitatif, dan R\&D. Bandung: Alfabeta.

[32] Riduwan. (2014). Metode Riset. Jakarta: Rineka Cipta. 